\title{
Anglican Church and the Development of Pentecostalism in Igboland
}

\author{
Benjamin C.D. Diara
}

\author{
Department of Religion and Cultural Studies, University of Nigeria, Nsukka- Nigeria \\ Nche George Christian
}

Department of Religion and Cultural Studies, University of Nigeria, Nsukka- Nigeria

\section{Doi:10.5901/jesr.2013.v3n10p43}

\begin{abstract}
The Anglican mission came into Igboland in the last half of the nineteenth century being the first Christian mission to come into Igboland, precisely in 1857, with Onitsha as the first spot of missionary propagation. From Onitsha the mission spread to other parts of Igboland. The process of the spread was no doubt, marked with the demonstration of the power of the Holy Spirit; hence the early CMS missionaries saw the task of evangelizing Igboland as something that could not have been possible without the victory of the Holy Spirit over the demonic forces that occupied Igboland by then. The objective of this paper is to historically investigate the claim that the presence of the Anglican Church in I gboland marked the origin of Pentecostalism among the Igbo. The method employed in this investigation was both analytical and descriptive. It was discovered that the Anglican mission introduced Pentecostalism into Igboland through their charismatic activities long before the churches that claim exclusive Pentecostalism came, about a century later. The only difference is that the original Anglican Pentecostalism was imbued in their Evangelical tradition as opposed to the modern Pentecostalism which is characterized by seemingly excessive emotional and ecstatic tendencies without much biblical anchorage.
\end{abstract}

Keywords: anglicanism, missionaries, traditions, pentecostalism, evangelicalism.

\section{Introduction}

Pentecostalism in its modern form has been one of the most significant new spiritual factors in the Christian church in the past four to five decades. Western historians tell the story of Pentecostalism as if it began in the beginning of the $20^{\text {th }}$ century in the United States of America. But references to the charismatic gifts of the Holy Spirit abound in the literature of the Eastern churches from the earliest times (Chatfield, 1998: 102). The Bible contains the most vivid account of the first Pentecostal and Charismatic episode in Acts 2.1-4. Thus Pentecostalism and Charismatism belong to a very ancient Christian tradition of spiritual enthusiasm born out of personal encounter with the saving power of Christ. Today this tradition has been modernized to a great extent as Pentecostal emphasis is now placed on miracle and prosperity.

"Modern Pentecostalism" as the present researchers terms the contemporary practice of Pentecostalism, however, began to have a major impact on Anglicanism and other mainline church traditions in the 1960s, first in the United States of America (Chatfield, 1998: 102). To that effect there is now an International Anglican Organization known as SOMA (Sharing of Ministries Abroad), whose aim is to share charismatic insights, teaching and experience throughout the Anglican world. African types of ecstatic Christianity have affected Anglican experience in a number of places, notably in the Caribbean, in Latin America and in parts of Africa especially in Nigeria and Igboland in particular, where the African Independent Churches are active. 
Naturally, the Anglican Church has an all-embracing tradition. It is catholic and evangelical, liberal and conservative, charismatic/Pentecostal and traditional. According to a one-time Archbishop of Canterbury, George Carey (Lambeth, 1998: 2) "Its (Anglican) styles vary from the simple to the elaborate, from evangelical to catholic, from charismatic to traditional, or indeed form a combination of these various traditions".

Consequently, Anglicanism lives with a broad spectrum of opinions, and traditions within its membership. The main contrast is between the low-church tradition (i.e. the Evangelicals) and the High-church tradition (i.e. the Anglo-Catholics). Originally a product of English Christianity, that contrast has marked many of the other churches of the Anglican Communion through the bias of the missionary agencies.

In West Africa, Ghana was influenced early by Society for the Propagation of the Gospel [SPG] missionaries, who increasingly in the $19^{\text {th }}$ century reflected a High-Church position, while Nigeria was influenced by the Church missionary Society [CMS] who stood for the evangelical tradition. Hence there was delineation of territories between Missionary agencies in West Africa. This made it easy for two different Anglican traditions to grow in the same area side by side. But within Nigeria, however, there was no variety of traditions. It was only the evangelicals; the Church Missionary Society who worked in the Country, hence Nigerian Anglicanism is wholly evangelical.

This means that Anglicans worldwide are used to a variety of traditions. Some think of Anglican church as either predominantly catholic or predominantly evangelical, but the fundamental truth is that Anglicanism is neither catholic nor evangelical, but both. That the Evangelical tradition of the Anglican Church is connected to modern Pentecostal movement world-wide and in Igboland in particular viz-a-viz the evangelical spirit of the Church Missionary Society cannot be out rightly denied. The doctrine and liturgy of the Anglican Church as an Evangelical church contain sound biblical elements of Pentecostalism. No wonder the CMS missionaries who brought the gospel to Igboland carried out their missionary work in Igboland with a somewhat Pentecostal zeal especially in their destruction of idols and evil forests. Once a person became a Christian, the following day, the missionaries went to his house to destroy charms, idols, shrines and other elements that symbolized his former religion (Okwueze, 1986: 12). This was a practical demonstration of charismatic power showing that Anglicanism is not only Evangelical but also Pentecostal in tradition.

\section{The Root of Evangelicalism and Pentecostalism}

The spirit of reform broke out in Europe with surprising intensity in the sixteenth century with Martin Luther as the Father of the Reformation, giving birth to evangelical traditions and shattering the papal leadership of the Western Church. Four major traditions emerged initially: Lutheran, Reformed, Anabaptist and Anglican (Shelley, 1982). Bloody struggles between the Catholic Church and the new churches followed and Europe was ravaged by war before it became obvious that Western Christendom was permanently divided hence the denominational concept of the Christian church. Thus, it was the evangelical movement that gave birth to the Anglican Church among other churches. The Reformation did not only give rise to evangelicalism, it also brought about the development of Pentecostalism. This was how it developed: In the $17^{\text {th }}$ and $18^{\text {th }}$ centuries the religious trend in England changed the course of world history. All classes of religious thoughts were imbued with rationalism so that there was a general spiritual lethargy within the church. The Industrial Revolution in Britain at this time also transformed the agrarian industry which in turn affected the level of individual commitment to religion and spirituality adversely. The resultant spiritual lethargy in Britain during this period forced William Laud, the opponent of the prevailing deistic doctrines of the time to call for a devout and holy life among Christians in 1728. John Wesley was greatly influenced by this call to spiritual revival (Agha, 1997). .

In order to revive the spiritual life of the people, different Christian societies were formed by those who caught the vision of evangelical revival. Group of young men in London formed the 
earliest Christian society in 1678 . The objective was to pray together, study the Scriptures, cultivate new spiritual life, preach the gospel, give aids to the needy, etc (Agha, 1997). The number of the societies had grown to about one hundred in 1700. In 1702, J ohn Wesley's father, Samuel Wesley formed his own society in Epworth in England (Walker, 1970). These profound changes and spiritual revolution throughout England primarily resulted in the "Evangelical Revival". The first signs of spiritual awakening manifested in the early part of the eighteenth century. From different backgrounds and approaches, the Evangelicals wished to cure the church of worldliness and to rekindle in the body of the church a sense of sin and the enabling grace of Christ to save sinners.

Like other revivalists such as the "Born Again" and Pentecostal revivalists, the Evangelical revivalist had to face the issue of whether to work within the existing churches, with the existing leaders and liturgies some of which they criticized and wished to change. In this case they would concentrate their effort on their mission of saving souls and leave the politics of church organization to others. Alternatively, they could emphasize doctrine, secede from the existing churches, formulate new liturgies, and constitute their followers into new churches. To do so is to run the risk of losing the momentum of the movement for saving souls, changing lives and settling into the routine of church organization.

Furthermore, the revivalists were also to grapple with a problem that is at the heart of evangelization, the relationship between preaching and pasturing, fishing and shepherding, mission and church. Nevertheless, John Wesley did not intend to secede from the Anglican Church, he wished to reform the Anglican Church from within. But before his death in 1791, his followers had formed three groups - the Wesleyan Methodists, the Calvinist Methodists and the Anglican Evangelicals. The Calvinist Methodist group led by George Whitefield became the leading missionary force to America while the Wesleyan Methodists and the Anglican Evangelicals proceeded to Africa. Eventually, America and Africa had to become the greatest Pentecostal strongholds in the world. Thus, the evangelical revival of the $18^{\text {th }}$ century gave birth to Pentecostal movement in the $20^{\text {th }}$ century.

\section{Origin of the Anglican Church in Igboland}

Following his acceptance to join Evangelicalism in England in 1786, William Wilberforce vowed to devote his energies to the abolition of slave trade which had its greatest source in Africa and Nigeria in particular. He thus joined a small group of evangelical clergymen and influential laymen committed to the cause of missionary movement. The members of the fellowship group included Charles Grant of the East India Company, Thomas Clarkson and Zachary Macauley of the Sierra Leone Company, Lord Teigumouth, a former Governor General of India, and others. It was a combination of their interests in India and Africa, and the anti-slavery campaign that moved them to favour a rekindling of the fire of evangelization, and the establishment in 1799 of a society for missions to Africa and the East (Ajayi, 1994).

This missionary society was later named the Church Missionary Society (CMS). Thus, the Church Missionary Society was founded by a group of sixteen clergymen and nine laymen in 1799. This was at a time when the Evangelicals were few in number and their influence in the church very limited. They believed that the injunction to spread the Gospel was to all Christians as individuals, and not to the church as an organization, but that evangelization required to be done within the context of the church because the converts would eventually need to be constituted into a church, which is a branch of the existing church. The evangelicals also saw foreign evangelization as an essential part of their vision to revive the spiritual life of the church..

The greatest labour of the Church Missionary Society centred on the campaign against slavery and slave trade. When all the evils connected with slave trade became clearly known, many good Christians and Christian Organizations began to speak openly against its continuation. With the passing of time, the movement for abolition of slave trade became influential even in the British Parliament. 
Victory crowned the labours of the evangelicals towards abolition of slave trade on $23^{\text {rd }}$ February, 1807 when the back of the opposition against abolition of slave trade was broken. The battle, however, continued for complete emancipation until age and poor health forced the leader of the Evangelicals, William Wilberforce, out of the parliament. The skills of a young evangelical named Thomas Fowel Buxton were immediately enlisted and he assumed the leadership of the "Holy enterprise". On $25^{\text {th }}$ July, 1833, four days before Wilberforce died, the reality of the passage of the Emancipation Act by the British Government came, freeing slaves throughout the British Empire (Shelly, 1970).

The liberated African slaves, among whom was a Nigerian of the Yoruba extraction namely, Ajayi Crowther, were settled in Sierra Leone in a place that was named "Freetown". This was a settlement established by the Society for Black Poor with the approval of the British Government, where settlers, the Nova Scotians and the Maroons, many of whom were already Christians were settled. In the settlement, there was the problem of ethnic loyalties among the liberated slaves, hence while attempts were being made to hold them together, there was continuity of old values, such as holding fastidiously to ethnic biases. These gave rise to the scientific study of native languages and adaptations of traditional instincts to the new development. The nostalgia for home became real with the heightening of inter-ethnic rivalries. One of the outcomes of this development was the successful planting of Christianity (Anglicanism) among the Yoruba in 1842 (Okeke, 1994).

The success of the Yoruba mission in turn stimulated the Igbo in Freetown into seeking a way of bringing the gospel to their countrymen. Already there was a powerful Igbo Association in Freetown. It was this Association that petitioned the Local Committee of the CMS in Freetown through Bishop Vidal, that Christianity be extended to Igboland. Before then, British Government had launched an expedition in 1854 to the Niger; and the report had reached the CMS in London about the prospect of the Niger for missionary work (Onyeidu, 2001). The CMS then organized a missionary outreach to Niger under the Rev. J.C Taylor of Igbo decent. Taylor and his team left for Onitsha in 1857.

On their way to Onitsha Rev. Samuel Ajayi Crowther was directed by the CMS authority to join them from the Yoruba mission. The team with Rev. Crowther now leading arrived at Onitsha on July 26, 1857, and on July 27 they were formally welcome by the traditional ruler of Onitsha, Obi Akazua and his elders-in-council. The church was then planted and the mission successfully inaugurated in Igboland.

Before this time Igboland was in complete spiritual darkness as the light of the gospel was yet to be extended to the people. The Anglican Church thus became the mother of the Christian mission in Igboland in 1857. The Church being an Evangelical church came along with the seed of Pentecostalism which is essentially an intrinsic aspect of the Evangelical tradition which the Anglican Church represents (Jones, 1952: 253). Although, the Pentecostal seed planted by the Anglican Church did not germinate immediately, its potentiality remained viable until the 1960s 70 s when it sprouted with remarkable signs and marks.

After the successful inauguration of the mission, Crowther left Lokoja and Taylor resumed the leadership of the Igbo mission to which he was totally committed. I nitially, due to lack of missionary personnel and the opposing evangelistic strategy between Crowther and Taylor, the mission could not spread fast to other parts of Igboland outside Onitsha. While Taylor saw the urgent need of reaching out with the gospel to other towns and villages, Crowther argued for strengthening of Onitsha base before any outreach.

Perhaps lack of personnel also militated against the work initially. The mission was only extended to Bonny at the request of the king of Bonny in 1864. Taylor visited Obosi, Oko, Nsugbe and Nkwelle but they could not be occupied for the reasons expressed above. In 1872 and 1874 the two main outstations of Onitsha, namely; Osomari and Asaba were established respectively. Later on the Onitsha station again extended the mission to Obosi (Okeke, 1994: 19). Gradually, each of the Igbo mission centres began to initiate evangelistic outreaches and the mission gradually began to grow. By 2002, there were 20 Dioceses of the mission with countless number of 
church stations.

The word of God which the Anglican Church first preached and taught in Onitsha from 1857 thus became the sine qua non for an effective Evangelico-Pentecostal tradition among the entire Igbo people. The CMS team, saw the Igboland as a whole as Satan's stronghold and themselves as the agents of God who had come to wage a determined spiritual battle against Satan. Subsequently, they had cultural and theological encounters with the people who were by then ardent worshippers of the spiritual forces that pervaded the Igboland. There were challenges and confusion. But in all, the power of the Holy Spirit prevailed. Thus, the Anglican mission introduced Charismatism/Pentecostalism in Igboland before ever churches with exclusively Pentecostal traditions came, about a century later.

\section{Development of Pentecostalism in Igboland}

In the pre-independence period, Pentecostalism was not a serious Christian system in Igboland because at that time the Christian missionary ideology bred a society of Igbo people who were strongly attached to the value of church membership. Church membership was seen as a part of modern life and hence a fashionable mode of life, while traditional religious life was seen as an outdated mode of life. Thus there was a boost in church membership. The organizational structure of the church was so firmly parish based, and people's sense of church membership was so high (Kalu, 1978).

Communities competed in building church infrastructure; and church buildings became an aspect of interdenominational rivalry. The value of individual Christian profession, practice and spirituality was not yet prominent among church members because nobody would want to be seen as unorthodox or heretical. By then the Aladura and prayer house spirituality was still in its infancy. Their members who were mostly Anglicans often acted surreptitiously. They would hide their white garments until they got to their worship ground. The consciousness of the stigma of being seen as unorthodox and rebellious to the church was so strong. But with the religious freedom which the Nigerian Independence initiated in 1960 the latent seed of Pentecostalism which was planted more than a century ago by the Anglican missionaries sprouted and grew swiftly in Igboland.

Discussing the factors that facilitated the positive response of the Igbo people to the message of Christianity, Kalu (1978: 317) refers to the "finger of God" as a veritable factor. By this Kalu agrees to the fact that the power of the Holy Spirit was instrumental to much of the conversions recorded among the Igbo people during the missionary days. To him, the nature of Christianity and the spiritual powers of its propagators contributed a great deal in the conversion of Igboland to Christianity in those early days. Nationalists and social scientists may not want to believe that the Holy Spirit contributed to the success recorded by the missionaries but the fact remains that it is only the power of God that can truly liberate the lives of men from the dominion of Satan.

From the early stage of Christianity in Igboland Church life has been characterized by one kind of church or extra-church charismatic movement or the other. In the pre-Independence period, a number of pseudo-Pentecostal movements flowed in some parts of Igboland, and ebbed as rapidly as they had grown. In most cases, the death of the founders brought about an almost immediate end to the movements until about the mid-seventies when Evangelical cum Pentecostal movement came to take firm root in Igboland through the ministry of the Scripture Union. To a great extent, the Anglican Church has been instrumental to this development having served as the nursing mother of Pentecostalism from its "seedling" stage to its present "full grown" stage. Below is the account of Pentecostal development in Igboland.

\section{Garrick Braide Pentecostalism}

In the midst of the First World War, Garick Braide's ministry swept through Southern Igbo area from Bakana, one of the villages of the Niger Delta. Garrick Sokari Braide, an Anglican by church 
denomination, introduced a new and radical form of evangelism in the Niger Delta area, which involved launching of frontal attacks on idols and charms and observance of strict spiritual discipline. Through his evangelism methods and spiritual practices, the entire Niger Delta and the surrounding Southern I gbo area witnessed a swift religious awakening.

Although his methods may not all be biblically justified, they nevertheless attracted very many people to the Christian faith. Whereas Christianity was introduced to the natives through teaching the creed, the Lord's Prayer, catechism, etc., Braide adopted a more radical and practical approach such as waging practical wars against idols with a view to proving to the people that there was no power in them. He did not bother himself with teaching creeds and the rest of Christian catechism, which were extremely difficult in view of high illiteracy rate among his people. His chief method as represented by Tasie (1978) was:

To organize a crusade against charms, fetishes and idols, probably believing that until the people lost faith in the powers of these objects they would not find peace in Christianity. His demands upon his hearers were simple: that they should destroy fetishes, confess their sins and put absolute faith in the sufficiency of Christ, He prescribed for coverts strenuous religious exercises, which helped them to cultivate a certain Christian discipline. He emphasized prayer sometimes specifying the numbers of times a day; he encouraged fasting and promoted the practice of praising God in local songs and shoutings. (p. 336)

Braide's movement appeared to pose a threat to Bishop James Johnson's position, and hence caused a breach between Braide and the church of the Niger Delta Pastorate (Anglican Communion). In 1918, Braide died and his followers founded a new church known as Christ Army Church. According to Kalu (1978), "by 1939, the movement had ebbed". The death of the founder himself would naturally affect his movement adversely hence the tendency for the movement to gradually go out of existence, especially as his followers had joined a new church.

\section{Prayer House Pentecostalism}

The "Prayer House" movements sprang up in Igbo land as a somewhat offshoot of the "Aladura" movements. Most founders of the Prayer House movements were members of the mainline churches who at one time or the other and for one reason or the other had attended the "Aladura" prayers and had been so influenced. The difference between the two is that members of the Prayer House still fulfill some membership obligations to some mainline (orthodox) churches while those of the "Aladura" have completely broken away from the orthodox churches and constituted themselves into their own independent churches.

During the period between the political independence of Nigeria and the subsequent civil war of 1967-1970, the orthodox churches were almost in the same spiritual state as ordinary social groups. Describing the spiritual state of the churches of this period, F.L. Bolton (Bolton, 1992) writes:

The church was in exactly the same state as the nation, in darkness. There was virtually no life in the churches. As the Lord Himself said, if then the light in you is darkness, how great is the darkness (Matthew 23). Every Sunday morning, for as long as I can remember, hundreds and thousands and even million of Ibo flocked into the churches; Anglicans, Methodists, Baptists, Presbyterians, Catholics, all sorts of denominations. But most of them would have died and gone to hell. Most of them believed they were saved through being baptized and through being good. We probably knew that Jesus died for our sins, whatever that was, but it means little or nothing. Liberal theology reigned. Very few people believed the Bible. And virtually everyone believed the age of miracles in the church was past,. If one wanted spiritual power one became or consulted an occultist, spiritualist or a native doctor. And there were many of these. People wanted a reality and a spirituality that eluded them. But it certainly 
would not have occurred to them to look for this spirituality in the churches. The churches had a form of religion but denied the power of it. (cf. I/ Timothy 3:5). (p.5)

It was in this atmosphere of spiritual paucity and poverty that "Prayer House" movements began. The Prayer House groups not only prayed a lot, they also preached from the Bible but an attentive listener could easily identify subtle deception. They preach and teach much but their sermons and doctrines are far from the gospel. The operation of the "Holy Spirit" was quite bizarre. The "Holy Spirit" would fall upon only the special ones and when it did come, the manifestations were more or less demonic convulsions. Under the power of the "Holy Spirit", they would "prophesy", pray for healing and carry on in an exhibitionist and self-important manner. There was a lot of discipline for spiritual power by way of fasting and very long period of prayer for both the prophets and their congregations. The healers were successful in the act of healing. They sometimes healed even those who were suffering from incurable diseases. They surrounded themselves with religious paraphernalia and other emblems; and they slept with Bible under their pillow and wore crosses blessed by the prophet for purpose of protection (Kalu, 1996).

It is therefore, not surprising that those who became the cardinal Evangelicals and Pentecostals in Igboland had themselves been involved in one prayer house or the other, it was there that most people who had a thirst for the deeper spiritual things end up, thinking they had found God in the prayer houses.

\section{Evangelical Pentecostalism}

Shortly after the end of the civil war in 1970, three young Anglicans namely, Stephen Okafor, Arthur Oraizu and Raphael Okafor who later became a Bishop in the Anglican Church, revolutionized the contemporary Pentecostal conception in Igboland. Before then, they were members of the Ufuma prayer House as it is commonly called, though its real name is practical Christian Prayer Band",. The name "Ufuma Prayer House" is more commonly used in referring to this Prayer Band because the headquarters is based at Ufuma in Anambra State where the founder, Sophy Okoro, an Anglican from Ovoko-Nsukka, was married (Bolton, 1992). Stephen, Arthur and Raphael eventually had personal encounter with Jesus Christ and left the prayer band and began to preach the gospel of repentance and salvation through faith in Jesus Christ (Bolton, 1992). They became the foundation members of a brand of Scripture Union which became a Pentecostal movement rather than an evangelistic agency in the Anglican Church.

Thus, a Pentecostal wind began to blow in Igboland and consequently many discovered that they possessed spiritual gifts. The face of Scripture Union gradually changed, and it moved from evangelical to a Pentecostal exhibition of the charismata. At a point, a split occurred in the membership as some members became critical of the turgidity in the mission churches and even haughty in their perception of those they regarded as "carnal brethren" who did not have Holy Ghost baptism. Many of such "Spirit-filled Christians" within the S.U. membership as they called themselves, most of whom were Anglicans, withdrew from the mission churches and founded their own churches while the rest constituted themselves into a strong Pentecostal factor in the Anglican Church and other mission churches (Kalu, 1996). In the Anglican Church, the Pentecostal factor came to be known as the Evangelical Fellowship in the Anglican Communion (EFAC) (Achunike, 2004).

\section{Revival of the Original Anglican Spirit of Pentecostalism}

The original Anglican spirit of Pentecostalism in Igboland was fanned into flame in the inauguration of the Evangelical Fellowship in the Anglican Communion (EFAC) in Nigeria in 1978. The post inauguration retreat was held at Bishop Cockin Church Centre (BCCC) Atta in Imo State from $26^{\text {th }}$ to $29^{\text {th }}$ June, 1979 at the instance of the then Diocesan Bishop of Owerri, Benjamin C. Nwankiti 
(Nkwoka, 2000). The retreat was attended mainly by a few clergymen who were beneficiaries of EFAC International Scholarship Programmes and other Evangelical Bodies like Scripture Union and Nigerian Fellowship of Evangelical Students (NIFES). EFAC thus became the modern Pentecostal and Charismatic movement in the Anglican Communion. EFAC is an evangelical movement which believes in, preaches and practices Pentecostalism in its modern form hence the present writer describes it as "modern Pentecostalism in the Anglican Church". Members of the Fellowship are committed to meeting the felt need of reviving the original Evangelical-charismatic task for which the Anglican Church was known since its inception in Igboland. It was established not to compete with any existing group in the church as some people seem to believe, but to reactivate Christian spirituality, evangelism and holiness in the church following the general negligence of the task of evangelism, and deterioration in the moral life of both the clergy and the laity of the Church (Nwigwe, 1999).

As a Pentecostal movement, EFAC practices speaking in tongues, prophecy, divine healing, deliverance, etc. Members emphasize the importance of Pentecostalism and charismatism both in the church and in individual life of the Christian. They believe in the phenomenon of "baptism" or "infilling" of the Holy Spirit in the life of the believer. They believe that every true believer in Christ must receive the baptism or infilling of the Holy Spirit just as the earliest disciples did on the Pentecost day. They believe that to be filled with the Holy Spirit is the same thing as baptism with the Holy Spirit which John the Baptist prophesied that Christ would be performing in his ministry (Jn. 1:33) and that it complements new birth in the sense of being born again with water and the Spirit as stated in John 3:5. EFAC members believe that the Holy Spirit "comes" or "falls" upon believers with observable signs, especially that of speaking in tongues, such that anybody who cannot speak in tongues is yet to be baptized with the Holy Spirit. They believe that speaking in tongues and prophecy should be freely practiced in the Church. Most of them believe that prophecy is the same thing as vision and as such any church that has no prophet(s) automatically has no vision, and members of such churches run the risk of perishing eternally for "where there is on vision the people perish". Like most Pentecostals, EFAC members mix up biblical issues. For instance, many, especially women and youths, do not know that speaking in tongues is a means of speaking to God while prophecy is a means of speaking from God, hence prophecy is simply hearing from God and communicating what has been heard or received to the people of God in plain language which they can understand. Prophecy does not use speaking in tongues as a medium of either reception or communication.

EFAC understand prophecy only in the sense of foretelling and not in the sense of forth telling, and in most cases, they confuse speaking in tongues with prophecy. In this sense, some EFAC members claim to be prophesying when they speak in tongues and try to interpret them. The EFAC lays special stress on the gifts of the Holy Spirit as described in Romans 12 and I Corinthians 12. One of the gifts which the members emphasize so much both in their teaching and in practice is divine healing. They often cite such scriptural expressions as "Healing is the children's bread", "By his stripes we are healed"; "He sent his words and his words heal us of all our diseases".

On the basis of such scriptural expressions many EFAC members tend to believe that taking of medication during sickness is a mark of carnality or faithlessness. They believe and teach that every type of sickness can be healed with faith through prayer alone so long as the person concerned is at right with God. Thus, EFAC teaches that sin and lack of faith constitute a barrier to receiving divine healing and as such for one to receive divine healing one has to be holy and to have faith. Also, EFAC believes that if a sick person does not have faith or is not holy he can receive divine healing on the basis of another person's faith and holiness.

EFAC teaches that there is an intrinsic connection between divine healing and the atoning work of Christ on the Cross such that when Christ said, "It is finished" while on the Cross, victory over sickness was inclusive in the finished work. Members believe that through the Great Commission Christ had given believers the authority and power to minister divine healing, especially as he said, "And these signs shall follow them that believe... they shall lay hands on the 
sick and they shall recover" (Mk. 16:17). Thus, prayer for the sick is paramount in the ministry of the EFAC.

Every EFAC preacher is also a divine healer; hence every EFAC crusade or revival is essentially a forum for divine healing. Usually as a part of the publicity for crusades and other outreach programmes, sick people are invited to come and receive healing. At the end of prayer for the sick some people may be healed while some may not, and that is a usual experience, but some EFAC members will usually attribute it to lack of faith or holiness on the part of those who are not healed. Sometimes they will describe such situation to imply the act of resistance of the demons behind the people's sicknesses, believing that every sickness has a demon behind it. The alternative then is that those whose sicknesses are not cured by ordinary prayers may have to be subjected to deliverance or exorcism.

EFAC lays much stress on spiritual warfare and deliverance. Members often quote Ephesians 6:12, "For we are not contending against flesh and blood, but against the principalities, against the powers, against the world rulers of this present darkness, against the spiritual hosts of wickedness in the heavenly places". To this end, some EFAC members almost propagate the doctrine of demonology, believing that there are demons in almost everything. They believe that there are demons of sickness, demons of fornication and adultery, demons of drunkenness, demons of lies, etc.

In the bid to demonstrate spiritual power some members of EFAC, especially the younger ones tend to practice iconoclasm, that is, attitude of trying to convert people by destroying their idols and other elements of their religious belief. Such ones destroy people's shrines and altars without their consent thinking that by so doing they will turn from idolatry and become Christians. Some even go to the extent of establishing their own ministries and dedicating them to pulling down of altars. Apparently, the fact that the practice of pulling down of altars and destroying of shrines and idols is possible without resistance on the side of the spiritual powers that inhabit such elements is enough proof that such Christians who do them possess a stronger spiritual power.

These and other Pentecostal tendencies in Igboland have been intensified by the contemporary religious environment of Nigeria. There is this wind of Pentecostalism blowing across almost every Christian denomination in the country today. As a result of this, most churches today emphasize, both in doctrine and practices, the reality of spiritual gifts such as divine healing, exorcism, prophecy, glossolalia, etc. And most of the activities of the churches have become charismatic and Pentecostal in outlook.

\section{Conclusion}

Positive responses to the gospel which was first preached in Igboland by the Church Missionary Society of the Anglican Church could not have been possible apart from the transforming power of the word of God and the convincing influence of the Holy Spirit. The power of God was indeed demonstrated in many ways, especially in the clearing and building of churches in evil forests, deliverance of the people from satanic socio-religious practices such as divinity possession and human sacrifice. Consequent upon such charismatic demonstrations which clearly showed the invincible power of the Holy Spirit over satanic forces Christian spirituality was introduced to Igbo people first by the Anglican Church thereby planting the seed of Charismatism/Pentecostalism in Igboland before the arrival of others.

Initially, members of Mainline churches could not freely identify with the new form of Pentecostal movement. But following the political independence of Nigeria in 1960 religious freedom was observed among Nigerians and Igbos in particular and consequently, attachment to membership of the mainline (mission) churches became less strong. This was more or less as a result of the general atmosphere of freedom, which the Independence of the Country initiated.

Although the civil war, which followed almost immediately, tended to rob the freedom from Nigerians, the end of the war in 1970 initiated an era of full-blown joy and freedom for the people. 
One of the results of that situation was religious bigotry; and consequent upon that, Pentecostal and pseudo-Pentecostal movements gradually became the order of the day in the Igbo Christian cosmology.

\section{References}

Achunike, H.C. (2004) The Influence of Pentecostalism on Catholic Priests and Seminarians in Nigeria, Onitsha: Africana First Publishers Ltd.

Adiele. S. N. (ed) (2001) The Anglican Church in Nigeria, Aba: Jone Venture. Productions.

Agha, A.U. (1997) Early European Mission to West Africa, Enugu: Calvary Side Printing and Publishing Co.

Ajayi., J.F.A. (1965) Christian Mission in Nigeria (1841-1891): The Making of a New Elite, London: Longman.

Ayandele, E.A. (1966) The Missionary Impact Of Modern Nigeria, 1842-1914: A Political and Social Analysis, London: Longman.

Barrett, C.K. (1974) The Holy Spirit and The Gospel, London: Sheldon Press.

Basden, G.T. (1966) Niger Ibos, London: Frank Cass and Co. Ltd.

Boer, J.H., (1966) Pentecostal Challenge, Nigeria: Gaskiya Publishers.

Bolton, F.L. (1992) And We Beheld His Glory, Harlow: Christ King Pub. Co.

Bonke, H. (2007) Holy Spirit Revelation \& Revolution: Exploring Holy Spirit Dimensions, Orlando: E R Productions Llc.

---- (2005) Evangelism by Fire, Orlando: Full Flame Llc.

Chatfield, A., (1978) Something in Common, Nottingham: St. John's Extension Studies.

Crowther, S.A. \& Taylor, (1859) The Gospel on the Banks of the Niger, London.

Diara, B.C., (1997) Mid-week Prayer: A Forum for Divine Blessings and Solutions To Problems in the Anglican Church. Enugu: Computer Edge Publishers.

Ekechi, F.K., (1972) Missionary Enterprise and Rivalary in Igboland, 1857-1914, London: Fran Cass.

Evans, G.R. \& Co. (ed), (1991) The Anglican Tradition, Londao: Spck/Fortress Press.

Graham, B. (2008) The Holy Spirit (New Edition), Nashville: Billy Graham Evangelistic Association.

Harrinck. C., (1994) The Charismatic Movement, Housten: Den Hertog B.V.

Harper, M., (1978) A New Canterbury Tale, England: Grove Books.

Hickey, D., (1978) Miracle, Hoddes: Stonghton Press.

Hollenweger, W.J. (1978) The Pentecostals. London, SCM Press.

Hughes, P., (1952) The Reformation in England, (vol. 1). London: Hollis \& Carter

Hursteield, J., (1965) The Reformation Crises, London: Edward Arnoid Publisher.

I femesia, C.C., (1978) South Eastern Nigeria in the Nineteenth Century. U.S.A.: Nok Publishers International.

Igwe, G.E., (2000) Church Union in Nigeria, Umuahia: Ark Publishers.

Ilogu, E., (1985) Christianity and Igbo Culture, Onitsha: University Publishing Press.

Kalu, O.U. (1996) The Embattled Gods: Evangelization of Igboland, Lagos \& London: Minaj Publishers.

Kalu, O.U. (1978) Divided People of God, London: Nok Publishers.

Kalu, O.U. (1990) "Broken Covenant: Religious Change in Igbo Historiography" Neve Zeitschrift Furmissionwissenschaft, Separa, Abdruck.

Nkwoka, A.O. \& Co. (ed.), (2000) The Church's Mandate and $21^{\text {st }}$ Century Mission, Kaduna: EFAC Nigeira Publication.

Nwigwe, N.S. (1999) EFAC as Youthful Charismatism in Anglican Communion, A Seminar paper, Department of Religion, U.N.N.

Okeke, D.C. (1994) "The Church in Igboland" in the Anglican Church in Nigeria, Nigeria: Macmillan.

Okocha, S.K., (1998) The Holy Spirit and You, Aba: Rumok Publishing House.

Omoyajowu, A. (1994) The Anglican Church in Nigeria, Lagos: Macmillan.

Onyeidu, S.O., (2001) Christianity and Onitsha Primal Society: The Anglican Contribution, Enugu: MBE.

Shelley, B.L. (1982) Church History in Plain Language, Taxas: World Book Publishers.

Tasie, G.O.M., (1978) Christian Missionary Enterprise in the Niger Delta 1864-1918, Leiden: E.J. Brill.

Walker, W. (1970) A History of Christian Church, New York: Charles Scriber's Sons. 